\title{
Reviewing the information paradigm
}

Citation for published version (APA):

Barreto Torres de Mendonca Narciso, M. (2022). Reviewing the information paradigm: the role of online reviews in the regulation of information in EU consumer law. [Doctoral Thesis, Maastricht University]. ProefschriftMaken. https://doi.org/10.26481/dis.20220309mb

Document status and date:

Published: 01/01/2022

DOI:

10.26481/dis.20220309mb

Document Version:

Publisher's PDF, also known as Version of record

\section{Please check the document version of this publication:}

- A submitted manuscript is the version of the article upon submission and before peer-review. There can be important differences between the submitted version and the official published version of record.

People interested in the research are advised to contact the author for the final version of the publication, or visit the DOI to the publisher's website.

- The final author version and the galley proof are versions of the publication after peer review.

- The final published version features the final layout of the paper including the volume, issue and page numbers.

Link to publication

\footnotetext{
General rights rights.

- You may freely distribute the URL identifying the publication in the public portal. please follow below link for the End User Agreement:

www.umlib.nl/taverne-license

Take down policy

If you believe that this document breaches copyright please contact us at:

repository@maastrichtuniversity.nl

providing details and we will investigate your claim.
}

Copyright and moral rights for the publications made accessible in the public portal are retained by the authors and/or other copyright owners and it is a condition of accessing publications that users recognise and abide by the legal requirements associated with these

- Users may download and print one copy of any publication from the public portal for the purpose of private study or research.

- You may not further distribute the material or use it for any profit-making activity or commercial gain

If the publication is distributed under the terms of Article $25 \mathrm{fa}$ of the Dutch Copyright Act, indicated by the "Taverne" license above, 


\section{SUMMARY}

This thesis examines the regulation of pre-contractual information in consumer contracts, looking at both the European Union's (EU) law-based regulation and market-based regulation. The EU consumer law-based information paradigm has been severely criticized for years due to its inability to inform consumers effectively. Accordingly, the EU legislator and the literature have been trying to find solutions to fix it. In recent years, online review mechanisms have arisen as one of the most relevant sources of information to consumers. Every day, millions of consumers consult online reviews to decide whether to conclude a variety of contracts. Consumers seem to value reviews and to actively look for them to take informed contractual decisions.

By establishing a parallel between these two dimensions, this thesis looks into how online review mechanisms regulate the flow of pre-contractual information in consumer contracts, and whether there are lessons to be learned from these mechanisms when it comes to improving the EU lawbased information paradigm. In other words, this thesis analyses online review mechanisms as a possible solution to the shortcomings faced by the EU law-based information paradigm. In particular, this thesis answers the question 'How do, can and should online review mechanisms contribute to the information paradigm in EU consumer law? Through doctrinal, empirical and interdisciplinary research, this project characterizes and compares the two information paradigms and shows that online reviews can and should be looked at not only as a problem or as a threat to consumer protection but also as a solution to the shortcomings of mandated disclosure.

Chapter 2 analyses how legal scholarship characterizes the information paradigm, and what solutions have been proposed to tackle the paradigm's shortcomings. Chapter 2 shows that, while the information paradigm is mentioned in several EU consumer law studies, it is rarely described, but instead used as a stepping stone for further points. Chapter 3 describes and analyses the results of a study conducted on nearly 1,500 pre-contractual information duties, scattered across 15 legislative instruments in the field of EU consumer law. This analysis shows that while the literature's characterization of the information paradigm is not incorrect, it is indeed incomplete and it ignores important trends and nuances. Chapter 4 presents a critical analysis of the work of the Court of Justice of the European Union (CJEU) concerning qualitative concerns with pre- 
contractual information in EU consumer legislation, particularly transparency requirements. Chapter 4 shows that the CJEU seems reluctant to deal with transparency and quality issues in legislative instruments other than the Unfair Terms Directive. Chapter 5 suggests an interpretative path towards broader but more defined duties to guarantee quality in pre-contractual information in EU consumer law, exploring the possibility of a principle of quality in EU consumer law. Chapter 6 characterizes online reviews as a source of pre-contractual information and shows how online reviews regulate informational flows in consumer contracts. In addition, Chapter 6 explores the dynamics between online review mechanisms and pre-contractual duties to inform. After the characterization of both the EU law-based information paradigm and the online review-based information paradigm, Chapter 7 compares these two paradigms. Chapter 7 also explores different concrete scenarios where online reviews can contribute to the EU consumer regulation of precontractual information.

Broadly speaking, this thesis argues that a stronger interaction between online review mechanisms and EU law can prove essential towards achieving more informed, truly empowered consumers. At its core, this thesis does not suggest that online reviews should be 'incorporated' in consumer legislation, or necessarily that consumer legislation should be amended to resemble the type of information conveyed by online reviews. The co-existence of legislation-based and market-based information sources is not detrimental to the consumer - quite the contrary -, as long as the robustness of the latter, including, but not limited to, its reliability, is controlled or incentivized by the market or public regulators. The main role that EU consumer law should play regarding online review mechanisms as a source of information is to create incentives for their development. This study also reaches relevant conclusions concerning the characteristics and delimitation of the existing EU law-based information paradigm. In broad terms, this thesis argues that the EU lawbased information paradigm contains some solutions to its shortcomings in itself and that its qualitative framework can play a crucial role in that, if further developed. 